cathair ghriobháin

Author(s): T. F. O'R.

Source: Gadelica: A Journal of Modern Irish Studies, Vol. 1, No. 3 (1913), p. 189

Published by: Gadelica: A Journal of Modern Irish Studies

Stable URL: http://www.jstor.org/stable/30057856

Accessed: 26-06-2016 06:13 UTC

Your use of the JSTOR archive indicates your acceptance of the Terms \& Conditions of Use, available at

http://about.jstor.org/terms

JSTOR is a not-for-profit service that helps scholars, researchers, and students discover, use, and build upon a wide range of content in a trusted

digital archive. We use information technology and tools to increase productivity and facilitate new forms of scholarship. For more information about JSTOR, please contact support@jstor.org.

Gadelica: A Journal of Modern Irish Studies is collaborating with JSTOR to digitize, preserve and extend access to Gadelica: A Journal of Modern Irish Studies 
Chonnachtach a muinighin lóin na Caillighe* Muimhnighe do bhi si nios cuilánta nó mar ba gnáth léith do bheith. ¡j do bhi si oidhche áividhe 'na suidhe go corrach gogach os cionn na tineadh, 1 do bhi coilean madraidh aig an Gcailligh Mhuimhnigh dár bha ainm Birrin, 7 adubhairt an Chailleach Chonnachtach gur cham srón Bhirraoin. 'An le mo ghadhar-sa déarthá sin?' ar an Chailleach Mhuimhneach, aig breith ar an Gcailligh Chonnachtaigh 7 dá cur amach ar an doras. 1 adubhairt an Chailleach Chonnachtach go rachadh do chasaoid a masla le ó Conchubhair Sligigh. 'Leath ubhaill. $\rceil$ é bearnuighthe ni thiubhrainnse ar ó Conchubhair féin,' ar an Chailleach Mhuimhneach. Iar sin ghluais an Chailleach Chonnachtach, agus nior comhnuidheadh léith go raibh aig ó Conchubhair Sligigh, i. ri Connacht, 1 do rinne casaoid a masla leis. 'Dar láimh mo mhic a Gcill Charbáin,' ar an ri, 'do bhéarfadsa creach na Mumhan liom a n-éiric h'easonóra-sa.' 1 do chuir fios 7 teachta ar mhaithe Connacht chuige, 7 do ghluaiseadar rompa go coigeadh Mumhan.

A third version, closely resembling that of $G$, is found in $23 \mathrm{~N} 25(\mathrm{~N})$. It may be noted that all three texts appear to come from districts not far apart (South Ulster and North Leinster). I have edited the spelling of G somewhat, but retain some characteristic forms like aig, nó $(=n a ́)$, do $(=a)$ bheith. For leath ubhaill $\rceil^{e}$ é bearnuighthe $\mathrm{G}$ has le(?)ithubhaille 7 é bearnaidh ; $\mathrm{N}$ omits. For Cill Charbaiin, the spelling of $\mathrm{N}, \mathrm{G}$ has Cill Charbuin. $\mathrm{N}$ makes the dog's name Bioraoin; G, Birrin and Birraoin.

T, F. O'R,

\section{cathair ghriobháin}

The word griobhan is one unknown to the dictionaries. I have met it only in the phrase cathair ghriobháin meaning 'a labyrinth, an inextricable place or position.' An instance occurs in F. Ó Maolchonaire's Desiderius (1616), p. 189 : do réidhighis as an ccathair ghriobháin a ttárla ag na heiricidhibh úd mé. Keating also employs the phrase, TBBh. 210: ag congbháil an pheacthaigh $i$ gcathair ghriobháin na coire, as nach léir dhó a leas do lovgaireacht. Molloy in his Lóchrann na Gcreidmheach (1676) several times uses the phrase in the sense of ' a dilemma ': do thuit tú san pholl dhubh $\rceil_{\rceil}$san gcathair ghriomhain as nach ttigir, p. 347. an $c[h]$ athair ghriobhainsi $\rceil_{7}$ an labirintum ina gcurthar thu, ibid. 348. don chathair ghriomhain, i. don pholl tuaithchill, lea gclaoidhtear na heiviceadh le na raidhtibh féin, ibid. p. vii. z. (For poll tuaithil, "whirlpool, maelstrom; (fig.) vicious circle,' cf. Molloy p. 292 : do thuit tú san bpoll tuaithchill as nach ttigir is nach bhfoghair foras, acht ag gabhail timchiol choidhche)

Atkinson (Glossary to "Three Shafts') explained griobhán as "griffin " (i.e. griobh, gribhingneach); but the connection between 'a labyrinth' and 'a griffin' is not obvious. Rather must griobhan be ultimately referred to the late Latin griphus (from the Greek), ' an intricate question, a puzzle, enigma.' The immediate original of cathair ghriobhain is, perhaps, most likely to be found in one of the medieval romances which were translated or adapted into Irish.

In the printed texts quoted above the $i$ of griobhan is left unaccented; but Atkinson writes griobhan, and the Latin griphus has also $i$ long.

T. F. O'R. 